\title{
Single Mothers' Survival Strategies of University Students During COVID-19 Pandemic
}

\section{Priyono Tri Febrianto}

Department of Primary School Teacher Education, Faculty of Science Education, Universitas Trunojoyo Madura, 69162, Bangkalan, East Java Province, Indonesia Corresponding Author: priyono.febrianto@trunojoyo.ac.id

\section{ARTICLE INFO}

Publication Info:

Research Article

How to cite:

Febrianto, P. T. (2021). Single

Mothers' Survival Strategies of

University Students During

COVID-19 Pandemic. Society,

9(1),19-36.

DOI: 10.33019/society.v9i1.301

Copyright (C) 2021. Owned by Author(s), published by Society

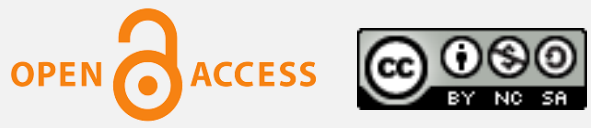

This is an open-access article.

License: Attribution-

NonCommercial-ShareAlike (CC BY-NC-SA)

\section{ABSTRACT}

The COVID-19 pandemic impacted the social and economic sectors. Family, the smallest social unit, is experiencing the impact, particularly for the woman as single-parent. Being a single parent is either a choice, decision, or condition that must be accepted due to the spouse's passing or other condition. Single parents carried numerous burdens alone, including earning a living and raising the children. These burdens have a significant impact on single parents. This study aims to reveal single-parent families' survival mechanisms. The research applied a qualitative method by interviewing single mothers from university students in East Java Province, Indonesia. This study used the theory of survival mechanism proposed by James Scott. The study found that instabilities generated by the COVID-19 pandemic produced enormous diminishing income. Such ordeals faced by single parents are burdensome because they initially had to support the family amid the feeble economy. Income vulnerability becomes a deep concern for single mothers. Pandemic COVID-19 caused these mothers to empower themselves and develop various survival strategies. The mothers from middle-class families live frugally and selective when they buy something they need. While mothers from lower-class families did different survival mechanisms, range from careful spending, owe some money, and open a business using their ex-husband's savings. Furthermore, they are also working overtime, empowering their children to help with the work, diversifying jobs by opening food stalls up to have an online shop. Therefore, it can be assumed that the COVID-19 pandemic has made single parents struggle even more to fulfil their family needs.

Copyright (C) 2021. Owned by Author(s), published by Society. This is an open-access article under the CC-BY-NC-SA license. 
Received: January 26, 2021;

Accepted: April 19, 2021;

Published: April 23, 2021;

Keywords: COVID-19 Pandemic; Single Parent; Survival

Mechanisms; Survival Strategies

\section{Introduction}

During the COVID-19 pandemic, economic needs increase, and parents must pay for their children's education. Therefore, a study of single parents is important to determine the survival of women who became single parents during the COVID-19 pandemic. Knowing their condition, it is hoped that they will become the basis for government policies in dealing with economic problems, especially single-parent families. A single parent is a parent who raises children without the support of a partner or raises children alone. Hammer \& Turner (2001) as cited in Haryanto (2012) define a single parent as a single parent who has children who still live with them.

Meanwhile, Sager defines a single parent as a parent who raises their children without the partner's presence, support, and responsibility (Haryanto, 2012). The 2015 Inter-Census Survey Data (Survei Penduduk Antar Sensus or SUPAS) found 81.2 million families in Indonesia, where women as head of households were 19.45 million. Meanwhile, BPS data for 2018 shows that there are 10.3 million households in Indonesia, with $15.7 \%$ women as heads of households. The causes of women becoming heads of households include divorce, husband's death, husbands are sick, husbands are unemployed, and their husbands leave them without providing a living.

Single parents are generally widows who still bear children. Husna (2018) states that widows who receive assistance from the Feminization of Poverty program in East Java are on average low-income widows and have difficulty fulfilling their children's education. They are unable to provide proper education because work is uncertain. Widows, as well as single parents, are very vulnerable to socio-economic conditions that decline due to the lack of economic access for some women, especially those from the lower middle class (Fitrianingrum, 2014)

Being a single parent is either a choice, decision, or condition that must be accepted due to the spouse's passing or other conditions. Layliyah (2013) argued that a single parent is a robust person and plays a dual role in being both father and mother for their children due to balancing those two role models. Thus, single mothers inevitably ought to play dual gender roles in children's presence, tenderness of mothers, and toughness of fathers (Goldscheider et al., 2013; Hasanah \& Widuri, 2014; Jones et al., 2002). Mothers had to add masculine traits to replace a father figure for their children on top of their femininity.

Several factors caused one to become a single parent, such as divorce, death-related conditions, out-of-wedlock pregnancy without the baby's father knowing, and other causes that lead to the absence of the father figure (Mailany, 2013). An individual could decide to be a single parent to live separately from a partner, which usually occurs to someone who strives for a better life rather than being locked in a marriage relationship. Other possible causes for a single parent are misfortunes, such as their partner passed away, went missing, or imprisoned.

Previous research noted that single parents are obliged to raise the children without a partner's assistance (Greeff \& van der Merwe, 2004; Guttmann \& Rosenberg, 2003; Utami \& Hanani, 2018). They ended up doing duties alone that were usually done together, such as caring for their children at home, taking care of household chores, earning income, and handling children's education. Although sometimes ex-spouses provide some life support, the absence of a partner is a challenge for single parents.

Copyright (C 2021. Owned by Author(s), published by Society. This is an open-access article under the CC-BY-NC-SA license. https://doi.org/10.33019/society.v9i1.301 
Nevertheless, single mothers often prioritise their children's education and happiness, in which they must split their time to secure a living and caring for their children (Rahayu, 2017). Furthermore, they have to arrange a balanced time between work and home matters carefully, since they unable to rely on their ex-spouse's funding and at the same time, they have to support their children. Likewise, single fathers are required to reconfiguring their roles as well. Apart from being the breadwinners, single fathers also do the house chores and care for their children. Thus, it shows that single parents offer dual roles as mothers and fathers simultaneously (Flug \& Kasir, 2006; Nilsen et al., 2017).

Damaske et al. (2017) stated that single mothers are vulnerable to economic shocks in the family and bear a much higher burden than single fathers. Economic shocks arise when a single mother has difficulty meeting financial needs while the income she gets is only for meeting basic needs. Previous research has also found that poor women who are single mothers are more likely to experience economic decline and become more impoverished, especially in the absence of good and low-skilled job opportunities (Ahn, 2014; Brady \& Burroway, 2012; Broussard et al., 2012).

Being a single mother automatically becomes the primary breadwinner in the family. A single mother who initially does not work is likely to become a worker to make ends meet. Research by Wu \& Eamon (2011) states that being a single mother will increase women's participation in the workforce. Women who initially depend on their husbands for life will become independent after divorce, or their husbands die. Meanwhile, another study states that single mothers who do not receive economic support from their ex-husbands' experience decreased psychological well-being (Choi \& Jackson, 2011; Kanji, 2010; Taylor \& Conger, 2017). This happens to single mothers who have never worked before the divorce, have low education, or do not have unique skills and expertise.

Choi \& Pyun (2013) stated that single mothers who get financial support from ex-husbands could guarantee children's care and education. Even though they are divorced, some single mothers are still provided with a living by their ex-husbands to meet the needs of their children, including children's education. This is very helpful for single mothers in raising their children. Previous studies have also stated that the burden felt by single mothers is the economic pressure of the absence of a partner so that it is associated with poor health, stress, unemployment, and problems in overcoming conflicts in the family (Rousou et al., 2013; Taylor \& Conger, 2014; Van Lancker et al., 2014).

The burden of single mothers is getting heavier, especially for single mothers who live in poverty. The absence of a partner, low education, and having more than one child causes single mothers to be economically vulnerable and have the potential to become increasingly poor (Mencarini et al., 2017). Previous studies have stated that economic pressure has made singleparent mothers take a side job to support their children (Anggraini, 2014; Hawita, 2016; Layliyah, 2013). This is because the income from the main job of single mothers is not sufficient for life, especially for children's education.

Previous studies found that women who had worked before the divorce did not face serious obstacles because they were accustomed to fulfilling the necessities of life. However, women who did not work before the divorce and did not have special skills will find it difficult and become odd jobs (Hanim, 2018; Novita, 2016; Lianda, 2019). A single mother who previously did not work experienced a shock of socio-economic conditions in her life. Hasanah \& Widuri (2014) emphasised that single mothers' socio-economic pressures play a dual role as mothers and fathers simultaneously. 
The security of single mothers relies on three things, namely wages or salaries, social security, and child support. Besides, children in single families are more likely to live in poverty than children from intact families (Bowman \& Wickramasinghe, 2020). Single mothers will feel helped by the existence of social security to ensure the life of their family. Without social security, single mothers face many obstacles in fulfilling family needs. Previous studies have also stated that the lack of health insurance for single-mother families can have economic impacts such as difficulties in paying for health costs (Bjarnason et al., 2010; Gonzales et al., 2011; Wu \& Eamon, 2013).

Harkness et al. (2019) stated that economic pressure due to reduced income due to the absence of a partner causes the pattern of parenting for children to change as well. Single mothers are less able to comply with the demands of their children because of the many daily costs that need to be borne. Meanwhile, Julia et al. (2019), in their research, states that working single parents can meet household needs, send children to school, and fulfil children's desires. Single mothers who work have an outstanding possibility to ensure the welfare of the family.

Low-income single parents would indeed undergo economic constraints due to the absence of a partner as financial support. This case ordinarily occurs to women who depend on their husbands' income or women whose income is far below their husbands. McCreary \& Dancy (2004) asserted that low-income single parents try to adapt and reconfigure their essence of happiness, that the current situation is better than before. Both single mothers or fathers will try to change as robust person to raise their children. On top of that, for low-income single fathers, childcare is undoubtedly a time-consuming and challenging responsibility.

Recent studies have noted that economic impact in a single parent's family expects them to change the family's economic behaviour (Hilton \& Desrochers, 2002; Pearl et al., 2012; Summefield et al., 2010). In this case, the declining incomes impose them on developing survival strategies and doing some survival mechanisms. Manning \& Brown (2006) suggested that single mothers hold lower expectations for child welfare compared to mothers who still together with the husband. A single parent is overwhelmed by doubt about raising their children alone since it is heavily related to their children's education. Preliminary studies also found that children raised by single parents with unstable economies are vulnerable to enduring financial difficulties, poverty and even fretted on their later economic wealth due to financial restraints (Corak et al., 2008; Heintz-Martin \& Langmeyer, 2019; Valletta, 2006).

Despite their social class, both single parents from the upper and lower classes should make ends meet due to their partners' shortage of financial support. Ellwood \& Jencks (2004) found that single parents cannot work optimally because they had to take care of their children. Unemployed single mothers are struggling to make a living while raising their children. Likewise, single fathers had to go home earlier because they have finished the house chores. Due to the number of works, single mothers are often burdened and overwhelmed by the responsibilities out of partner's support (Berridge \& Romich, 2010; Dudley-Marling, 2001; Lokshin et al., 2000). Moreover, lower-middle-class single mothers struggle to strive for more income due to the restrained domestic works as they cannot afford to pay for a nanny or domestic helper to look after their children.

Notwithstanding the lack of financial income, single-parent families have a preferably high personal affinity due to the small number of families and stories of their struggles (Walker et al., 2008). A divorced single parent thinks that the new life can be much better without the expartner's presence. Thus, single mothers and fathers seem more stringent than those who still together since single parents have an enormous responsibility to be role models and play double roles for their children.

Copyright (C 2021. Owned by Author(s), published by Society. This is an open-access article under the CC-BY-NC-SA license. https://doi.org/10.33019/society.v9i1.301 
Recent studies above have been assessing single parent's experience, cause, and impact. However, studies on single parents in the wake of the COVID-19 pandemic have not been explored yet. Therefore, this study becomes a predominant concern to address the single mothers' survival mechanisms, notably for those who had children in a university. In general, single mothers find it challenging to meet their daily needs, including the cost of education for their children. But some single mothers think about the future of their children, including higher education. A previous study stated that single mothers save and use social assistance so that their children can go to college (Astutik \& Nurchayati, 2018). The COVID-19 pandemic sparks an economic instability that affected almost all aspects, especially single-parent families, which become the family's backbone.

\section{Research Methodology}

This research employs a qualitative method that serves as communication between the researcher and informants. This type of research is descriptive. This method is also more adaptable and can be suited accordingly to the phenomenon. Criteria for selecting the informants were as follows; single mothers of university students. Such criteria were chosen due to the big spending of families that have to pay the university education fees. Therefore, this study aims to collect information on a single mother's survival strategies during the COVID-19 pandemic.

Furthermore, this study used snowball data collection. Key informants in this study indicate other informants following the criteria of this study. The key informants in this study tell other informants are following the requirements of this study. This study took 16 single mother female informants who have children who are currently in college.

The study area was done in regencies and city in East Java, Indonesia, namely Sidoarjo Regency, Gresik Regency, and Surabaya city. These areas were chosen due to the high living costs compared to the other regencies and municipalities in East Java Province.

Sources of data used in this study are primary data and secondary data. Primary data were obtained from the results of interviews conducted with informants with the criteria as stated earlier. Secondary data were obtained from literature studies and data from the government related to this research topic.

This study collected data within an in-depth interview and qualitative data analysis, using Miles \& Huberman (1994) concept, which applies an interactive and continuous data collection to the point where the data becomes saturated. The collected data are classified, categorised and presented based on the topic of research. Data analysis was carried out by conducting dialogue and discussing the findings in the existing relevant studies.

\section{Results and Discussion}

Various findings suggest that single parents have an enormous duty because they can bear all the life burdens without any support from a partner. Single parents are required to play a dual role in complementing each of a parent's gender roles. A single mother must play the role of both mother and father. Most divorced or left-by-passing single parents have challenging circumstances as they raised children and earned a living. In this case, both single mothers and fathers experienced the same thing of possessing greater responsibility to balance their work and domestic affairs.

Previous studies stated that widows whose husbands passed away generally experienced social benefit from their husbands' pension, leaving them with no other income if the mother is previously staying at home mom (Korb, 2010; Gillen \& Kim, 2009). Such plights are prevalent in

Copyright (C) 2021. Owned by Author(s), published by Society. This is an open-access article under the CC-BY-NC-SA license. https://doi.org/10.33019/society.v9i1.301 
women who once depended on their partner's earnings or those who had insufficient income. Moreover, this condition is worsened by the mother's responsibilities to earn a living, take care of their children, and serve their children's education necessities.

Both single mothers or fathers have the same hurdle to work hard to maintain their families. Single mothers earn more living to support their children's needs, even if it means more work time and less time spent with them. Aquilino (2005) noticed that single parents struggle to make their children understand families' financial situation and teach them financial matters due to their lack of financial condition. Besides, weak family bonds push them to less able to pay attention and control their children's growth.

\subsection{Single parents social and economic condition during the COVID-19 pandemic}

Instabilities generated by the COVID-19 pandemic produced enormous diminishing income. Such ordeals faced by single parents are burdensome because they initially had to support the family amid the feeble economy.

One of the interviewees, NIT, who work in a factory, experienced financial instability during the COVID-19 pandemic. The instability forced her to find another option to earn a living. NIT is a single mother who divorced her husband, and she has four children since 2010.

NIT is a worker in a plywood factory who works glueing wood. Also, she sells hodgepodge to increase his income. Her financial condition was quite sufficient before the pandemic, though they depended on the small labour income working at the small factory. However, the financial condition worsened during the pandemic, and it requires her to set another strategy to meet the household necessities. Moreover, the factory's businesses are not as busy as usual throughout the pandemic. In NIT case, her family needs to keep increasing, yet the financial situation is currently facing a challenge.

NIT is a mediocre single mother and owns her life on the poverty line. The worsened financial situation of her family portrays that her family is highly vulnerable to poverty. In this case, NIT had to bear the responsibility to raise her children without her husbands' support. A study by Hutchings \& Michailova (2014) asserts that single mothers are responsible for taking care of their children's education and educating their children. Such cases found in NIT's experience, who struggled alone to raise four children by solely working as a factory worker. On the other hand, Bouye et al. (2009) also found that low-income single parents often had to suspend family needs due to financial shortages. NIT's life illustrates how hard it is for single mothers to survive the economic crisis during this pandemic.

Another informant, DWI, a middle-class single mother, endured this as well. Although she did not suffer a significant impact from the pandemic situation, she has a stable income. DWI admitted that she had to keep paying employees even though the income had fallen sharply.

DWI is a divorced single mother since the year 2017 and left with two children. DWI's has a stable financial condition because her ex-husband owns a company, and her first child is currently working as the company's successor. It means that her ex-husband's company supports her current financial incomes. Though the pandemic economic impact is not severe for her, DWI still ought to cut her spending because she still needs to pay for the employee's wages. Overall, single mothers will do their best to fulfil their family needs. In contrast, DWI is rather lucky because of the grown-up children capable of managing her ex-husband's company, which makes her able to receive a stable income. The case might differ when it comes to single mothers with young children who do not have the opportunity to be the company's successor.

Copyright (C 2021. Owned by Author(s), published by Society. This is an open-access article under the CC-BY-NC-SA license. 
The researchers found that working single mothers spend more time doing house chores than working due to the absence of a partner's support (Boushey, 2009; Fan, 2015; Skevik, 2004). Moreover, single mothers had to earn income and play a leading role as mothers who care for the family, especially if they have a toddler. Such conditions left single mothers less able to take maximum working hours. Sometimes, they get around by asking relatives to assist them with the house chores, for example, leaving the children with their grandmothers or other relatives. The double burden of a widow and breadwinner is often shared with extended family, especially grandmothers (D'Souza, 2000). As a result, mothers can focus on working and obtain maximum income.

Income vulnerability becomes a deep concern for single mothers. In this case, STE, which currently becomes a single mother for a month, shared her experience. Her husband died in an accident while she is unable to work due to the illness she had. Additionally, her children still need their parents' support. STE is worrying over the family's economic condition, which her husband no longer supported. Both STE's children are still in college, so she is worried about her children's education.

It can be seen that STE is worried about her family's survival amid the pandemic. STE still has two children who are in university, while she is not working and ill. She relies a lot on her husband's savings and compensation funding because of the husband's passing.

STE has a difficult time after his husband passed away recently. She shared that her husband was involved in an accident and passed away due to internal injuries. When the accident occurs, no one helped STE's husband out of coronavirus concern, which leads to late first aid and causes her husband's death. On the other hand, STE's husband is the only breadwinner of the family. These things left a deep sorrow for STE as she worries about her children's education. Previous studies found that single mothers are vulnerable to poverty and difficulty raising children than the intact family (Beeber et al., 2008; Maldonado \& Nieuwenhuis, 2015; Parish et al., 2008). Besides, Skari et al. (2002) also found that single mothers suffered stress and depression higher than single fathers, especially when they have children's burden and have no support from the ex-husbands.

Pandemic drives many people to have difficulties, especially for economic sectors. In this case, RIZ, our informant, shared her struggling story. RIZ is a single mother who runs a toy store in three branches in Gresik regency, East Java. RIZ's store income has fallen sharply due to the social distancing policy. Besides, she had to pay employees wages amid this decreasing revenue. RIZ is currently also paying off debts from her parents, while the income from the shop is decreasing.

RIZ has arguably undergone decreasing income due to the shift of customer behaviour during the social distancing policy, in which they prefer to put the primary needs above everything. She still had to pay for three employees worth wages amid the decreasing income. Before the pandemic, RIZ can earn at least six million rupiahs, while the pandemic makes the income falls to two or three million rupiahs only. On top of that, she still has the responsibility to pay for her children's tuition.

RIZ's took over the toy store after his husband passed away. RIZ has no other choice but to take over the store, even if she had no experience taking care of it while her husband was alive. She now has a double role in managing the store and taking care of house chores. Fulcher et al. (2015) found that single parents release their gender identity when taking care of their children and reconfigure their role in the family to earn a living and care for their children. Moreover, single parents have to be excellent role models for their children. For instance, Doherty \& Craft (2011) found that single mothers struggle to raise a son without a father present.

Copyright (C 2021. Owned by Author(s), published by Society. This is an open-access article under the CC-BY-NC-SA license. https://doi.org/10.33019/society.v9i1.301 


\subsection{Single parents survival mechanism amid COVID-19}

Single mothers implemented strategies to face economic pressures amid pandemic by adding another job to sustain family needs and raising children, and ensuring their education. Mothers who initially did not work and depended on her husband had no other choices instead of working to earn an income. A study done by Nixon et al. (2013) found that single parents' children have to adapt to the transition and challenge to a lack of protection compare to when their parents are still living together since single parents have to split their time and take on two gender roles at once.

Furthermore, single parents had to increase their working hours amid the pandemic to maximise a higher income and solve the economic shortages faced by KAN, who works overtime. Moreover, she opened a food stall that steered her on more extended working hours. KAN starts working from 5.30 am to $10 \mathrm{pm}$. This additional working hour demonstrates the persistence of a single mother to fulfil her family's needs, especially her youngest still has to attend school. KAN works harder though there is no support from her ex-husband and urges his son to help her work. KAN often gets loan money from her extended family to pay for her children's school needs.

However, busy single parents faced immense pressures and risks. Playing dual roles is challenging for them as they have to do everything alone. It is why single parents frequently face pressure and stress out of their duties and roles, in line with Cairney et al. (2003) study, which reveals that single mothers are more susceptible to stress and even leads to depression. Such cases are often found in middle-class single mothers, especially if the mothers are left with toddlers who need many necessities. Besides, previous studies also found that single parents are prone to stress due to the judgment of their children of having low self-esteem compared to children with complete parents (Bifulco et al., 2002; Landrigan et al., 2017; Mullins et al., 2010).

Being a single parent like KAN is undoubtedly much pressure, particularly when she left with four children without any support from her ex-husband. However, KAN stated she would not give up on the situation. Therefore, she tries to raise the children properly, regardless of the pressures and stress she endured. Streisand et al. (2009) found that single mothers will easily suffer stress and psychological pressure when their child is sick. In which such things are prevalent in single mothers with a low economy. Other previous studies have also stated that increased stress and depression in single parents influence their children's behaviour to perceive depression, anxiety, and anger, leading to juvenile delinquency (Keller et al., 2002; Kim \& Brody, 2005; Ng \& Wan Sulaiman, 2017).

On the other hand, middle-class single mothers employ a different survival mechanism when facing economic hardship during the pandemic. HMA, who appears from a prosperous family, said that she did not have many survival mechanisms but became more economical and only purchased the necessary items.

The HMA family adopts a simple lifestyle by saving expenses. Though she did not receive money from her son, it was still sufficient to meet the family needs. Therefore, the HMA survival mechanism is only to save money and buy the necessary things.

Being a single parent, especially a women, is prone to becoming poorer or getting poorer. This happens in a society where the backbone of the family is only the husband. When divorced or separated, the absence of income for the widow made poverty even more complicated. Poverty is divided into two types, namely structural and cultural poverty. Structural poverty is mentioned by Soemardjan as cited in Noerdin et al. (2006) that structural poverty is poverty suffered by a group of people because the social structure of the community cannot share in using the sources of income that are actually available to them.

Copyright (C 2021. Owned by Author(s), published by Society. This is an open-access article under the CC-BY-NC-SA license. https://doi.org/10.33019/society.v9i1.301 
Based on this definition, Soemardjan stated that groups of people who suffer from structural poverty, for example, are farmers who do not own land, farmers whose land is narrow, unskilled labourers, small entrepreneurs without capital, or so-called very weak economic groups. The essence of structural poverty is the absence of "productive relationships" in a community even though there are resources in that community. On the other hand, structural poverty in urban societies, for example, has more varied aspects.

This is due first; in general, poverty in urban communities is caused by the migration of rural residents to cities. Second, poverty occurs not because of an imbalance in the social structure but because the social structure is not conducive so that poor households cannot work productively. Meanwhile, the indicators used by the Central Statistics Agency to measure poverty are only based on quantitative figures, which include household income, household expenditure, daily consumption, and property ownership.

Poverty is a complex social problem. Yudhoyono \& Harniati (2004) classify poverty into three types. First, natural poverty, namely poverty caused by the low quality of natural resources and human resources. Second, cultural poverty is related to the attitude of a reluctant person to rise from poverty. Third, structural poverty, namely poverty due to institutional arrangements or social structures in society.

Cox as cited in O'Connor (2009) divides the causes of poverty into four parts, namely poverty due to globalisation, poverty related to development, social poverty, and consequential poverty. Meanwhile, Ruspini (2003) states that the party experiencing poverty the most are women. According to Ruspini, poverty has led to dependence, social neglect and lack of access for women. Besides, women often have no economic control and are paid lower wages than men.

The economic pressures experienced by single mothers in this study are related to poverty. The absence of skills or skills makes it difficult for women to manage the household economy and get a decent income. Also, being a labourer is done by women as single mothers because of the absence of land and proper economic access. On the other hand, the dependence of single mothers on ex-husbands is a factor in women's vulnerability to enter poverty.

Women as single mothers face the impact of economic burdens in meeting family needs. Previous studies have stated that single mothers tend to face financial losses than single fathers (Maldonado \& Nieuwenhuis, 2015). Women face economic difficulties in the market competition, which further increase the vulnerability of the family economy. On average, women earn less than men because of the distribution of wages based on gender (England et al., 2016).

Besides being economical, children of single parents also helped fulfil family needs, especially for grown-up children. In this case, LIA, whose husband passed away due to an accident, her son willingly earns an income. However, LIA did not force him to work since the son currently in university, and the pandemic caused many companies to postpone job vacancies.

As a single mother who has just lost her husband and in stroke condition, there are not many survival mechanisms that LIA did to raise the family income. Currently, LIA is no longer able to work, so she relies on her husband's savings. She discerned that the savings would run out while his two children are still in university. LIA said she did not want to burden his first son to support her life, especially when he gives pocket money for the third child. Being a single parent in some Asian countries is not easy. In Indonesia, which society adheres to a patriarchal culture, widows face social consequences apart from suffering economic difficulties. It is associated with a woman who fails to keep their family or relationship, especially for divorcees.

Copyright (C 2021. Owned by Author(s), published by Society. This is an open-access article under the CC-BY-NC-SA license. https://doi.org/10.33019/society.v9i1.301 
At the same time, widows who are dependants on their children are considered 'bad mothers', especially for those who are still of working age. Therefore, it is not surprising that KAN and LIA decided not to depend on their children.

Previous studies have stated that single mothers in Asia often receive a negative stigma and struggles to raise children (Lenette, 2013; Parker, 2015; Pohlman, 2015). Such labelling would put single mothers to social judgments, especially if they had to work late at night. Lau et al. (2017) found that single mothers often withdraw from social life due to the number of negative stigmas they received. In the end, a single mother chooses to focus on work and reduce social interactions.

Furthermore, single mothers are also diversifying their businesses model to increase their income concerning working more hours. It is experienced by OFI, who relies on the toy store business. OFI sells the store online and adds various things to sell, such as hand sanitisers, masks, and face shields in both offline and online stores. She did that to continue their business.

According to OFI, it can be seen that a single parent will undoubtedly find a way to meet family needs. In OFI's case, she opened an online store to survive. Moreover, OFI had to pay the employees' wages. Meanwhile, OFI admits that it is impossible to terminate the employee's contract because the store remains quite reliable.

Single mothers have such a heavy burden and had to survive for themselves and the children. Single mothers' welfare does not necessarily improve despite the high income (Bauman, 2002; Campbell et al., 2016; Gibson et al., 2017). It explains that though a single mother has a relatively stable life, the burden remains enormous. Besides, single mothers are often work in males' job field, which empowers them to work with no occupational gender differentiation. In OFI's case, she now manages the toy store business. In line with this, previous studies found that single parents' existence raises gender equality and increases women's work participation (Dunifon \& Kowaleski-Jones, 2007; Goldscheider et al., 2013; Mather, 2010).

Another survival mechanism found in single mothers is owed money. One of the interviewees, UTI, owed debts to make ends meet. UTI admitted that some needs could be covered with debt. UTI also hopes that she will be able to repay the loan once the pandemic is over. UTI is in debt to pay for her children's education. The need for internet quota for online learning during the pandemic caused the need for UTI to increase. UTI must also pay off the motorbike installments.

UTI is busy caring for their children and paid for their education. It is quite exhausting for her as the breadwinner. Even her youngest child had to work part-time at the cake ingredients store, which violates minor employment. However, UTI and her family had no other choice. Meanwhile, her ex-husband never supported her children since they divorced.

As a single mother, UTI struggles to raise children alone; even she had to do three jobs to support the family out of poverty. Lyter et al. (2004) mentioned that children in low-income families cannot access proper health care because their parents are busy working. Finally, children raised in single-parent families underwent economic deprivation, lessened quality and quantity of parental kinships, lose parental support, and have no control from the parents (de Lange et al., 2013; Manning \& Smock, 2000; Nepomnyaschy, 2007).

A single parent remains seeking as much as possible to raise their children amidst limitations. Previous studies have stated that the quality of children's education is influenced by the single parent's hard work, especially for the lower and middle class (Chou, 2012; Simms et al., 2009; Ziol-Guest et al., 2015). With that being said, there are various survival mechanisms that single mothers did, especially during the pandemic.

Copyright (C 2021. Owned by Author(s), published by Society. This is an open-access article under the CC-BY-NC-SA license. 
In the midst of the COVID-19 pandemic, single parents are surviving by maximising the efforts they can make to continue to be able to meet family needs. They perform survival mechanisms to survive and support their family. The survival mechanism is a theory put forward by James Scott as cite in Ritzer (2012) which discusses survival mechanisms among farmers.

Scott mentions that farmers can endure difficult years through "tightening the belt" which is eating only once a day and switching to poor quality foods. Scott explained that there are three ways the survival mechanism is carried out by the poor. First, reduce expenses, eat only once a day, and switch to low-quality foods. Second, using subsystem alternatives, namely small-scale selling, working as labourers or migrating to other places. Third, ask for help from social networks such as friends, neighbours, relatives, or ask patron protection.

Kraus et al. (2020) state that the COVID-19 pandemic affects people's income and purchasing power so that household (family) consumption also experiences an impact, so one strategy is to save money. Making savings is a real effort to survive, apart from decreasing income and experiencing a financial deficit. Meanwhile, people who experience a decrease in income end up using their savings for their daily lives (Gonzalez et al., 2020).

Based on the results of this study, single parents perform survival mechanisms to survive and meet family needs. Single parents include "tightening our belts" by not spending a lot of money. Single parent makes savings because income decreases, and there is also no other income.

The survival mechanism carried out by a single parent is not only limited to making savings but trying to open other alternative sources such as opening small shops and selling online. Their children also help their mother to work by selling to increase family income. Besides, single parents also make loans at financial institutions to cover economic shortages. These are survival strategies that single parents seek to support their families. Empowerment of single mothers can be carried out by the Ministry of Women Empowerment and Child Protection and the Ministry of Social Affairs to provide skills training for single mothers living in poverty. Besides, the Ministry of Social Affairs is expected to conduct regular data collection on the number of single mothers and ensure that children of single mothers receive a proper education. So far, there have been scholarships from the Ministry of Education and Culture for the poor, so there is only a need for synergy between ministries so that children of single mothers can have their education guaranteed.

\section{Conclusion}

The COVID-19 pandemic affected the economic well-being, particularly for single-parent families who suffers a decreasing income that challenges them to develop a survival mechanism. There are many challenges they face during the COVID-19 pandemic. They experience vulnerability due to reduced income, and they also have to continue to struggle to pay for the education of children who are currently studying at university. Besides, these singleparent mothers also have to do domestic work. The role of single-parent mothers is getting heavier during this COVID-19 pandemic.

Despite this, the COVID-19 pandemic empowered women. This study concludes that there are a variety of survival mechanism strategies developed by single-parent women. Middle-class single mothers develop various mechanisms to cope with the difficulties, such as adopting a frugal lifestyle and only spend money on necessary things. At the same time, lower-class single mothers developed more varied survival mechanisms. Ranging from making more savings, works in more hours, empowers their children to help with work, and diversifies jobs by 
opening food stalls up to sell goods online. The recommendation of this study is to increase economic empowerment for single-parent women to encourage them to be released from vulnerability and poverty traps and still be able to survive.

\section{Acknowledgement}

The author is grateful to express gratitude to the Rector of Universitas Trunojoyo Madura and those who have had the pleasure to cooperate during this study.

\section{Declaration of Conflicting Interests}

The author has declared no potential conflicts of interest concerning the study, authorship, and/or publication of this article.

\section{References}

Ahn, H. (2014). Economic well-being of low-income single-mother families following welfare reform in the USA. International Journal of Social Welfare, 24(1), 14-26. https:/ / doi.org/10.1111/ijsw.12095

Anggraini, Y. (2014). Penyesuaian diri menjadi "single parent" di Nagari Abai Siat, Kecamatan Koto Besar, Kabupaten Dharmasraya (Thesis). Padang: STKIP PGRI Sumatera Barat.

Aquilino, W. S. (2005). Impact of Family Structure on Parental Attitudes Toward the Economic Support of Adult Children Over the Transition to Adulthood. Journal of Family Issues, 26(2), 143-167. https:/ / doi.org/10.1177/0192513x04265950

Astutik, D., \& Nurchayati. (2018). Tantangan single mother berpendidikan rendah dalam memberikan pendidikan tinggi pada anak-anaknya. Character: Jurnal Psikologi.

Bauman, K. J. (2002). Welfare, Work and Material Hardship in Single Parent and Other Households. Journal of Poverty, 6(1), 21-40. https:/ / doi.org/10.1300/j134v06n01_02

Beeber, L. S., Perreira, K. M., \& Schwartz, T. (2008). Supporting the Mental Health of Mothers Raising Children in Poverty. Annals of the New York Academy of Sciences, 1136(1), 86-100. https:/ / doi.org/10.1196/annals.1425.008

Berridge, C. W., \& Romich, J. L. (2010). “Raising Him . . . to Pull His Own Weight”: Boys' Household Work in Single-Mother Households. Journal of Family Issues, 32(2), 157-180. https:/ / doi.org/10.1177/0192513x10380832

Bifulco, A., Moran, P. M., Ball, C., \& Lillie, A. (2002). Adult attachment style. II: Its relationship to psychosocial depressive-vulnerability. Social Psychiatry and Psychiatric Epidemiology, 37(2), 60-67. https:/ / doi.org/10.1007/s127-002-8216-x

Bjarnason, T., Bendtsen, P., Arnarsson, A. M., Borup, I., Iannotti, R. J., Löfstedt, P., . . Niclasen, B. (2010). Life Satisfaction Among Children in Different Family Structures: A Comparative Study of 36 Western Societies. Children \& Society, 26(1), 51-62. https:/ / doi.org/10.1111/j.1099-0860.2010.00324.x

Boushey, H. (2009). The New Breadwinner: Women now account for half of all jobs, with sweeping consequences for our nations economy, society, and future prosperity. In The Shriver Report: A Woman's Nation Changes Everything.

Bouye, K., Truman, B. I., Hutchins, S., Richard, R., Brown, C., Guillory, J. A., \& Rashid, J. (2009). Pandemic Influenza Preparedness and Response Among Public-Housing Residents, Single-Parent Families, and Low-Income Populations. American Journal of Public Health, 99(S2), S287-S293. https:/ / doi.org/10.2105/ajph.2009.165134

Bowman, D., \& Wickramasinghe, S. (2020). Trampolines not traps: Enabling economic security for single mothers and their children. New York: Research \& Policy Centre. 
Brady, D., \& Burroway, R. (2012). Targeting, Universalism, and Single-Mother Poverty: A Multilevel Analysis Across 18 Affluent Democracies. Demography, 49(2), 719-746. https:// doi.org/10.1007/s13524-012-0094-z

Broussard, C. A., Joseph, A. L., \& Thompson, M. (2012). Stressors and Coping Strategies Used by Single Mothers Living in Poverty. Affilia, 27(2), 190-204. https:// doi.org/10.1177/0886109912443884

Cairney, J., Boyle, M., Offord, D. R., \& Racine, Y. (2003). Stress, social support anddepression in single and married mothers. Social Psychiatry and Psychiatric Epidemiology, 38(8), 442-449. https:// doi.org/10.1007/s00127-003-0661-0

Campbell, M., Thomson, H., Fenton, C., \& Gibson, M. (2016). Lone parents, health, wellbeing and welfare to work: a systematic review of qualitative studies. BMC Public Health, 16(1), 188. https:// doi.org/10.1186/s12889-016-2880-9

Choi, J. K., \& Jackson, A. P. (2011). Fathers' involvement and child behavior problems in poor African American single-mother families. Children and Youth Services Review, 33(5), 698704. https:// doi.org/10.1016/j.childyouth.2010.11.013

Choi, J. K., \& Pyun, H. S. (2013). Nonresident Fathers' Financial Support, Informal Instrumental Support, Mothers' Parenting, and Child Development in Single-Mother Families With Low Income. Journal of Family Issues, 35(4), 526-546. https:// doi.org/10.1177/0192513x13478403

Chou, K. L. (2012). Familial Effect on Child Poverty in Hong Kong Immigrant Families. Social Indicators Research, 113(1), 183-195. https:// doi.org/10.1007/s11205-012-0088-7

Corak, M., Fertig, M., \& Tamm, M. (2008). A Portrait of Child Poverty in Germany. Review of Income and Wealth, 54(4), 547-571. https:/ / doi.org/10.1111/j.1475-4991.2008.00287.x

D'Souza, S. (2000). Poverty among Widows of Kinshasa, Congo. Journal of Health, Population and Nutrition, 18(2), 79-84. Retrieved from http://www.jstor.org/stable/23498686

Damaske, S., Bratter, J. L., \& Frech, A. (2017). Single mother families and employment, race, and poverty in changing economic times. Social Science Research, 62, 120-133. https:// doi.org/10.1016/j.ssresearch.2016.08.008

de Lange, M., Dronkers, J., \& Wolbers, M. H. J. (2013). Single-parent family forms and children's educational performance in a comparative perspective: effects of school's share of singleparent families. School Effectiveness and School Improvement, 25(3), 329-350. https:// doi.org/10.1080/09243453.2013.809773

Doherty, W. J., \& Craft, S. M. (2011). Single Mothers Raising Children with "Male-Positive" Attitudes. Family Process, 50(1), 63-76. https:// doi.org/10.1111/j.1545-5300.2010.01346.x

Dudley-Marling, C. (2001). School Trouble: A mother's burden. Gender and Education, 13(2), 183197. https:/ / doi.org/10.1080/09540250120051196

Dunifon, R., \& Kowaleski-Jones, L. (2007). The Influence of Grandparents in Single-Mother Families. Journal of Marriage and Family, 69(2), 465-481. https://doi.org/10.1111/j.17413737.2007.00377.x

Ellwood, D. T., \& Jencks, C. (2004). The Spread of Single-Parent Families in the United States since 1960. SSRN Electronic Journal. https:// doi.org/10.2139/ssrn.517662

England, P., Bearak, J., Budig, M. J., \& Hodges, M. J. (2016). Do Highly Paid, Highly Skilled Women Experience the Largest Motherhood Penalty? American Sociological Review, 81(6), 1161-1189. https:// doi.org/10.1177/0003122416673598

Fan, Y. (2015). Household structure and gender differences in travel time: spouse/partner presence, parenthood, and breadwinner status. Transportation, 44(2), 271-291. https:// doi.org/10.1007/s11116-015-9637-7

Copyright (C 2021. Owned by Author(s), published by Society. This is an open-access article under the CC-BY-NC-SA license. https://doi.org/10.33019/society.v9i1.301

31 
Fitrianingrum, E. (2014). Strategi Bertahan Hidup Janda Lansia. Paradigma, 2(3). Retrieved from https://jurnalmahasiswa.unesa.ac.id/index.php/paradigma/article/view/9474

Flug, K., \& Kasir, N. (2006). The single parent law, labor supply and poverty. Israel Economic Review, 4(1), 59-110. https:/ / ssrn.com/ abstract=2175604

Fulcher, M., Dinella, L. M., \& Weisgram, E. S. (2015). Constructing a Feminist Reorganization of the Heterosexual Breadwinner/Caregiver Family Model: College Students' Plans for their Own Future Families. Sex Roles, 73(3-4), 174-186. https://doi.org/10.1007/s11199015-0487-8

Gibson, M., Thomson, H., Banas, K., Lutje, V., McKee, M. J., Martin, S. P., . . Bond, L. (2017). Welfare-to-work interventions and their effects on the mental and physical health of lone parents and their children. Cochrane Database of Systematic Reviews. https:/ / doi.org/10.1002/14651858.cd009820.pub2

Gillen, M., \& Kim, H. (2009). Older Women and Poverty Transition. Journal of Applied Gerontology, 28(3), 320-341. https:/ / doi.org/10.1177/0733464808326953

Goldscheider, F., Scott, M. E., Lilja, E., \& Bronte-Tinkew, J. (2013). Becoming a Single Parent. Journal of Family Issues, 36(12), 1624-1650. https:/ / doi.org/10.1177/0192513x13508405

Gonzales, N. A., Coxe, S., Roosa, M. W., White, R. M. B., Knight, G. P., Zeiders, K. H., \& Saenz, D. (2010). Economic Hardship, Neighborhood Context, and Parenting: Prospective Effects on Mexican-American Adolescent's Mental Health. American Journal of Community Psychology, 47(1-2), 98-113. https:// doi.org/10.1007/s10464-010-9366-1

Greeff, A. P., \& van der Merwe, S. (2004). Variables Associated with Resilience in Divorced Families. Social Indicators Research, 68(1), 59-75. https:/ / doi.org/10.1023/b:soci.0000025569.95499.b5

Guttmann, J., \& Rosenberg, M. (2003). Emotional Intimacy and Children's Adjustment: A comparison between single-parent divorced and intact families. Educational Psychology, 23(4), 457-472. https:/ / doi.org/10.1080/01443410303213

Hanim, H. (2018). Peran perempuan single parent dalam pemenuhan fungsi ekonomi dalam keluarga studi kasus: Perempuan single parent pekerja di Pijat Refleksi Tosyma Jakarta Selatan. Jurnal Ilmu dan Budaya, 41(60), 7081-7100. Retrieved from http://journal.unas.ac.id/ilmu-budaya/article/view/465

Harkness, S., Gregg, P., \& Fernández-Salgado, M. (2019). The Rise in Single-Mother Families and Children's Cognitive Development: Evidence From Three British Birth Cohorts. Child Development, 91(5), 1762-1785. https:/ / doi.org/10.1111/cdev.13342

Haryanto, J. T. (2012). Transformasi dari Tulang Rusuk Menjadi Tulang Punggung. Yogyakarta, Indonesia: Arti Bumi Intaran.

Hasanah, T., \& Widuri, E. (2014). Regulasi Emosi Pada Ibu Single Parent. Jurnal Psikologi Integratif, 2(1), 86-92. Retrieved from http://ejournal.uinsuka.ac.id/isoshum/PI/article/view/225

Hawita, N. (2016). Peran Ibu dalam Menjalankan Pola Asuh Anak di RW 29 Kelurahan Simpang Baru Kecamatan Tampan (Studi Kasus Keluarga Single Parent). Journal Online Mahasiswa Fakultas Ilmu Sosial dan Ilmu Politik, 3(2), 1-14. Retrieved from https://jom.unri.ac.id/index.php/JOMFSIP/article/view/10953

Heintz-Martin, V. K., \& Langmeyer, A. N. (2019). Economic Situation, Financial Strain and Child Wellbeing in Stepfamilies and Single-Parent Families in Germany. Journal of Family and Economic Issues, 41(2), 238-254. https:/ / doi.org/10.1007/s10834-019-09653-z 
Hilton, J. M., \& Desrochers, S. (2002). Children's Behavior Problems in Single-Parent and Married-Parent Families. Journal of Divorce \& Remarriage, 37(1-2), 13-36. https:// doi.org/10.1300/j087v37n01_02

Husna, D. A. (2018). Efektivitas Program Jalin Matra terhadap Kesejahteraan Janda Miskin di Desa Sumberjo Kecamatan Sanankulon Kabupaten Blitar Ditinjau dari Ekonomi Islam. Martabat, 2(2), 201-218. https:/ / doi.org/10.21274/martabat.2018.2.2.201-218

Hutchings, K., \& Michailova, S. (2014). Research Handbook on Women in International Management. Cheltenham, United Kingdom: Edward Elgar Publishing. https:// doi.org/10.4337/9781781955031

Jones, D. J., Forehand, R., Brody, G. H., \& Armistead, L. (2002). Positive Parenting and Child Psychosocial Adjustment in Inner-City Single-Parent African American Families. Behavior Modification, 26(4), 464-481. https:/ / doi.org/10.1177/0145445502026004002

Julia, H., Jarnawi, J., \& Indra, S. (2019). Pola pengasuhan pada konteks kematangan emosional ibu single parent. Indonesian Journal of Counseling \& Development, 1(1), 31-49. Retrieved from https:/ / ejournal.iainkerinci.ac.id/index.php/bkpi/article/view/370

Kanji, S. (2010). Labor Force Participation, Regional Location, and Economic Well-Being of Single Mothers in Russia. Journal of Family and Economic Issues, 32(1), 62-72. https:// doi.org/10.1007/s10834-010-9198-z

Keller, T. E., Catalano, R. F., Haggerty, K. P., \& Fleming, C. B. (2002). Parent Figure Transitions and Delinquency and Drug Use Among Early Adolescent Children of Substance Abusers. The American Journal of Drug and Alcohol Abuse, 28(3), 399-427. https:// doi.org/10.1081/ada-120006734

Kim, S., \& Brody, G. H. (2005). Longitudinal Pathways to Psychological Adjustment Among Black Youth Living in Single-Parent Households. Journal of Family Psychology, 19(2), 305313. https:// doi.org/10.1037/0893-3200.19.2.305

Korb, B. R. (2010). Financial planners: Educating widows in personal financial planning. Journal of Financial Counseling and Planning, 21(2). Retrieved from https:/ / ssrn.com/abstract=2061309

Kraus, S., Clauss, T., Breier, M., Gast, J., Zardini, A., \& Tiberius, V. (2020). The economics of COVID-19: initial empirical evidence on how family firms in five European countries cope with the corona crisis. International Journal of Entrepreneurial Behavior \& Research, 26(5), 1067-1092. https:/ / doi.org/10.1108/ijebr-04-2020-0214

Landrigan, T. J., Kerr, D. A., Dhaliwal, S. S., Savage, V., \& Pollard, C. M. (2017). Removing the Australian tax exemption on healthy food adds food stress to families vulnerable to poor nutrition. Australian and New Zealand Journal of Public Health, 41(6), 591-597. https:// doi.org/10.1111/1753-6405.12714

Lau, Y. W., Picco, L., Pang, S., Jeyagurunathan, A., Satghare, P., Chong, S. A., \& Subramaniam, M. (2017). Stigma resistance and its association with internalised stigma and psychosocial outcomes among psychiatric outpatients. Psychiatry Research, 257, 72-78. https:// doi.org/10.1016/j.psychres.2017.07.027

Layliyah, Z. (2013). Perjuangan hidup single parent. Jurnal Sosiiologi Islam, 3(1), 88-102. Retrieved from http://jurnalfisip.uinsby.ac.id/index.php/JSI/article/view/39

Lenette, C. (2013). "I am a Widow, Mother and Refugee": Narratives of Two Refugee Widows Resettled to Australia. Journal of Refugee Studies, 27(3), 403-421. https:// doi.org/10.1093/jrs/fet045

Lianda, A. A. (2019). Analisis faktor-faktor yang mempengaruhi keputusan wanita bekerja sebagai buruh dalam meningkatkan pendapatan keluarga menurut perspektif ekonomi Islam (studi pada

Copyright (C) 2021. Owned by Author(s), published by Society. This is an open-access article under the CC-BY-NC-SA license. 
buruh wanita di pengasinan ikan Desa Tarahan, Lampung Selatan) (Thesis). Lampung: UIN Raden Intan.

Lokshin, M., Harris, K. M., \& Popkin, B. M. (2000). Single Mothers in Russia: Household Strategies for Coping with Poverty. World Development, 28(12), 2183-2198. https:// doi.org/10.1016/s0305-750x(00)00070-x

Lyter, D. M., Sills, M., Oh, G. T., \& Jones-DeWeever, A. (2004). The Children Left Behind: Deeper Poverty, Fewer Supports. Washington: Institute for Women's Policy Research.

Mailany, I. (2013). Permasalahan yang Dihadapi Single Parent di Jorong Kandang Harimau Kenagarian Sijunjung dan Implikasinya terhadap Layanan Konseling. Konselor, 2(1), 7682. https:/ / doi.org/10.24036/0201321828-0-00

Maldonado, L. C., \& Nieuwenhuis, R. (2015). Family policies and single parent poverty in 18 OECD countries, 1978-2008. Community, Work $\mathcal{E}$ Family, 18(4), 395-415. https:/ / doi.org/10.1080/13668803.2015.1080661

Manning, W. D., \& Brown, S. (2006). Children's Economic Well-Being in Married and Cohabiting Parent Families. Journal of Marriage and Family, 68(2), 345-362. https:// doi.org/10.1111/j.1741-3737.2006.00257.x

Manning, W. D., \& Smock, P. J. (2000). "Swapping" Families: Serial Parenting and Economic Support for Children. Journal of Marriage and Family, 62(1), 111-122. https:// doi.org/10.1111/j.1741-3737.2000.00111.x

Mather, M. (2010). U.S. Children in Single-Mother Families. Population Reference Bureau. Retrieved from https://www.prb.org/singlemotherfamilies/

McCreary, L. L., \& Dancy, B. L. (2004). Dimensions of Family Functioning: Perspectives of LowIncome African American Single-Parent Families. Journal of Marriage and Family, 66(3), 690-701. https:/ / doi.org/10.1111/j.0022-2445.2004.00047.x

Mencarini, L., Pasqua, S., \& Romiti, A. (2017). Single-mother families and the gender gap in children's time investment and non-cognitive skills. Review of Economics of the Household, 17(1), 149-176. https:/ / doi.org/10.1007/s11150-017-9385-x

Miles, M., \& Huberman, A. (1994). Research Design and Data Management. In Qualitative Data Analysis. Thousand Oaks, CA: Sage Publications.

Mullins, L. L., Wolfe-Christensen, C., Chaney, J. M., Elkin, T. D., Wiener, L., Hullmann, S. E., . . Junghans, A. (2010). The Relationship Between Single-Parent Status and Parenting Capacities in Mothers of Youth with Chronic Health Conditions: The Mediating Role of Income. Journal of Pediatric Psychology, 36(3), 249-257. https://doi.org/10.1093/jpepsy/jsq080

Nepomnyaschy, L. (2007). Child support and father-child contact: Testing reciprocal pathways. Demography, 44(1), 93-112. https:/ / doi.org/10.1353/dem.2007.0008

Ng, Y. Y., \& Wan Sulaiman, W. S. (2017). Resilience as Mediator in the Relationship between Family Functioning and Depression among Adolescents from Single Parent Families. Akademika, 87(01), 111-122. https://doi.org/10.17576/akad-2017-8701-08

Nilsen, W., Skipstein, A., Østby, K. A., \& Mykletun, A. (2017). Examination of the double burden hypothesis - a systematic review of work-family conflict and sickness absence. European Journal of Public Health, 27(3), 465-471. https:/ / doi.org/10.1093/eurpub/ckx054

Nixon, E., Greene, S., \& Hogan, D. (2013). “It's What's Normal for Me.” Journal of Family Issues, 36(8), 1043-1061. https:/ / doi.org/10.1177/0192513x13494826

Noerdin, E., Agustini, E., Pakasi, D. T., Aripurnami, S., \& Hodijah, S. N. (2006). Potret Kemiskinan Perempuan. Jakarta, Indonesia: Women Research Institute.

Copyright (C 2021. Owned by Author(s), published by Society. This is an open-access article under the CC-BY-NC-SA license. https://doi.org/10.33019/society.v9i1.301 
Novita, S. N. (2016). Upaya ibu sebagai single parent dalam memenuhi kebutuhan pendidikan anak studi single parent buruh tani di Nagari Aua Kuniang Kecamatan Pasaman Kabupaten Pasaman Barat (Thesis). Padang: STKIP PGRI Sumatera Barat.

O'Connor, A. (2009). Poverty Knowledge. Princeton: Princeton University Press. https:// doi.org/10.1515/9781400824748

Parish, S. L., Rose, R. A., Grinstein-Weiss, M., Richman, E. L., \& Andrews, M. E. (2008). Material Hardship in U.S. Families Raising Children with Disabilities. Exceptional Children, 75(1), 71-92. https:/ / doi.org/10.1177/001440290807500104

Parker, L. (2015). The theory and context of the stigmatisation of widows and divorcees (janda) in Indonesia. Indonesia and the Malay World, 44(128), 7-26. https:/ / doi.org/10.1080/13639811.2015.1100863

Pearl, A. M., French, B. F., Dumas, J. E., Moreland, A. D., \& Prinz, R. (2012). Bidirectional Effects of Parenting Quality and Child Externalizing Behavior in Predominantly Single Parent, Under-Resourced African American Families. Journal of Child and Family Studies, 23(2), 177-188. https:/ / doi.org/10.1007/s10826-012-9692-z

Pohlman, A. (2015). Janda PKI: stigma and sexual violence against communist widows following the 1965-1966 massacres in Indonesia. Indonesia and the Malay World, 44(128), 68-83. https:// doi.org/10.1080/13639811.2015.1100873

Rahayu, A. (2017). Kehidupan Sosial Ekonomi Single Mother dalam Ranah Domestik dan Publik. Jurnal Analisa Sosiologi, 6(1), 82-99. Retrieved from https://jurnal.uns.ac.id/jas/article/view/18142

Ritzer, G. (2012). Teori Sosiologi: Dari Sosiologi Klasik sampai Perkembangan Terakhir Postmodern. (8th ed.). Yogyakarta, Indonesia: Pustaka Pelajar.

Rousou, E., Kouta, C., Middleton, N., \& Karanikola, M. (2013). Single mothers' self-assessment of health: a systematic exploration of the literature. International Nursing Review, 60(4), 425-434. https:/ / doi.org/10.1111/inr.12044

Ruspini E. (2003) The social construction of health inequalities: The case of Italian women. In: Pasero U. (eds) Gender - from Costs to Benefits. VS Verlag für Sozialwissenschaften. https:/ / doi.org/10.1007/978-3-322-80475-4_7

Simms, M. C., Fortuny, K., \& Henderson, E. (2009). Racial and ethnic disparities among lowincome families. Retrieved from http:/ / webarchive.urban.org/publications/411936.html

Skari, H. (2002). Comparative levels of psychological distress, stress symptoms, depression and anxiety after childbirth - a prospective population-based study of mothers and fathers. BJOG: An International Journal of Obstetrics and Gynaecology, 109(10), 1154-1163. https:/ / doi.org/10.1016/s1470-0328(02)00968-0

Skevik, A. (2004). Family economy workers or caring mothers? Male breadwinning and Widows' Pensions in Norway and the UK. Feminist Economics, 10(2), 91-113. https:// doi.org/10.1080/13545700420000217739

Streisand, R., Mackey, E. R., \& Herge, W. (2009). Associations of Parent Coping, Stress, and Well-Being in Mothers of Children with Diabetes: Examination of Data from a National Sample. Maternal and Child Health Journal, 14(4), 612-617. https:/ / doi.org/10.1007/s10995-009-0497-7

Summefield, T., Young, L., Harman, J., \& Flatau, P. (2010). Child support and Welfare to Work reforms the economic consequences for single-parent families. Family Matters, 84, 68-78.

Taylor, Z. E., \& Conger, R. D. (2014). Risk and Resilience Processes in Single-Mother Families: An Interactionist Perspective. Defining Prevention Science, 195-217. https://doi.org/10.1007/978-1-4899-7424-2_9

Copyright (C 2021. Owned by Author(s), published by Society. This is an open-access article under the CC-BY-NC-SA license. 
Taylor, Z. E., \& Conger, R. D. (2017). Promoting Strengths and Resilience in Single-Mother Families. Child Development, 88(2), 350-358. https://doi.org/10.1111/cdev.12741

Utami, N. P., \& Hanani, S. (2018). Kebertahanan Perempuan Simalanggang Menjadi Single Mother. Turast: Jurnal Penelitian Dan Pengabdian, 6(1), 25-36. https:/ / doi.org/10.15548/turast.v6i1.683

Valletta, R. G. (2006). The Ins and Outs of Poverty in Advanced Economies: Government Policy and Poverty Dynamics in Canada, Germany, Great Britain, and The United States. Review of Income and Wealth, 52(2), 261-284. https:/ / doi.org/10.1111/j.1475-4991.2006.00187.x

Van Lancker, W., Ghysels, J., \& Cantillon, B. (2014). The impact of child benefits on single mother poverty: Exploring the role of targeting in 15 European countries. International Journal of Social Welfare, 24(3), 210-222. https:/ / doi.org/10.1111/ijsw.12140

Walker, J., Crawford, K., \& Taylor, F. (2008). Listening to children: gaining a perspective of the experiences of poverty and social exclusion from children and young people of singleparent families. Health $\mathcal{E}$ Social Care in the Community, 16(4), 429-436. https:// doi.org/10.1111/j.1365-2524.2008.00781.x

Wu, C. F., \& Eamon, M. K. (2011). Patterns and correlates of involuntary unemployment and underemployment in single-mother families. Children and Youth Services Review, 33(6), 820-828. https:/ / doi.org/10.1016/j.childyouth.2010.12.003

Wu, C. F., \& Eamon, M. K. (2013). Employment Hardships and Health Insurance Coverage in Single-Mother Families During and After the Great Recession. Affilia, 28(3), 273-283. https:// doi.org/10.1177/0886109913495665

Yudhoyono, S. B. \& Harniati. (2004). Pengurangan Kemiskinan di Indonesia : Mengapa Tidak Cukup dengan Memacu Pertumbuhan Ekonomi. (1st ed.). Bogor, Indonesia: Brighten Press.

Ziol-Guest, K. M., Duncan, G. J., \& Kalil, A. (2015). One-parent students leave school earlier: Educational attainment gap widens. Education Next, 15(2). Retrieved from https:/ / www.educationnext.org/one-parent-students-leave-school-earlier /

\section{About the Author}

Priyono Tri Febrianto obtained his Master's degree from Universitas Gadjah Mada, Indonesia, in 2004. The author is a Lecturer at the Department of Primary School Teacher Education, Faculty of Science Education, Universitas Trunojoyo Madura, Indonesia.

E-Mail: priyono.febrianto@trunojoyo.ac.id 